\title{
Whole-rock geochemistry of the Hili Manu peridotite, East Timor: implications for the origin of Timor ophiolites*
}

\author{
T. J. FALLOON ${ }^{1 \dagger}$, R. F. BERRY ${ }^{2}$, P. ROBINSON ${ }^{2}$ AND A. J. STOLZ ${ }^{2}$
}

'School of Earth Sciences and Centre for Marine Science, University of Tasmania, GPO Box 252-79, Hobart, Tas. 7001, Australia.

${ }^{2}$ School of Earth Sciences and CODES, University of Tasmania, GPO Box 252-79, Hobart, Tas. 7001, Australia.

\begin{abstract}
The Hili Manu peridotite occupies a key position at the outer limit of continental crust on the north coast of East Timor. Most models for the tectonic evolution of the Outer Banda Arc interpret peridotite bodies on Timor, such as Hili Manu, as fragments of young oceanic lithosphere from the Banda Arc (upper plate). However, recent workers have used major-element geochemistry to argue that the peridotite bodies on Timor were derived from the Australian subcontinental lithosphere. Our major, trace and isotopic geochemical study of the Hili Manu peridotite body supports a supra-subduction origin from either a forearc or backarc position for the Hili Manu peridotite. In particular, the wide range in $\mathrm{Nd}$ and $\mathrm{Sr}$ isotopic compositions, overlapping that of arc volcanics from the Sunda-Banda Island arc, and highly fractionated $\mathrm{Nb} / \mathrm{Ta}$ values indicate a supra-subduction setting. As there is no evidence for subduction beneath the rifted Australian continental margin, it is unlikely that the Hili Manu peridotite is Australian subcontinental lithosphere. This result, along with the clear supra-subduction setting of the Ocuzzi peridotite and associated volcanics in West Timor, gives support to the interpretation that the Miocene collision between the Banda Arc and the Australian continental margin has produced widespread 'Cordilleran'-style ophiolites on Timor.
\end{abstract}

KEY WORDS: Australia, geochemistry, Hilu Manu, ophiolite, peridotite, Timor.

\section{INTRODUCTION}

Fault-bounded peridotite bodies are common in suture zones and along major transcurrent faults. However, the tectonic significance of these bodies is debatable (Coleman 1971; Hamilton 1979; Dilek et al. 2000; Beccaluva et al. 2004). In East Timor, a peridotite body outcrops as a fault block on the north coast, on the margin of continental crust in a modern island arccontinent collision zone. This body is of particular interest, because later events have not obscured its position in the orogenic belt, and also because it has retained its high-temperature mineralogy. The peridotite (Hili Manu peridotite) is remarkably fresh and has a complex history of high-temperature processes recorded in its disequilibrium textures and mineral assemblage.

The most common rock type in this body is a clinopyroxene-poor lherzolite, but there are smaller proportions of clinopyroxene-rich lherzolite and harzburgite. The dominant mineral assemblage is olivine, orthopyroxene, clinopyroxene, spinel and calcic amphibole. Low-temperature hydrous minerals are restricted in distribution. The chemical composition of the peridotite is very similar to mantle-derived spinel lherzolite nodules and some alpine peridotites (Berry 1981). The internal variation of the peridotite suggests variable depletion by some combination of partial melting and liquid contamination of the residua.

Berry (1981) recognised three solid-state events from the mineral chemistry and texture. The earliest event is recorded by coarse exsolution lamellae of orthopyroxene in clinopyroxene porphyroclasts. These grains formed at $1250^{\circ} \mathrm{C}$. A later granoblastic texture equilibrated at $1100^{\circ} \mathrm{C}$, and finally the rocks were mylonitised at $800-1000^{\circ} \mathrm{C}$ and $800-2000 \mathrm{MPa}$.

The Hili Manu peridotite body could be part of either the Banda upper plate (the Banda terrane) or the lower Australian Plate. If the Hili Manu peridotite is derived from the Banda Plate, we should expect to see a suprasubduction zone geochemical signature, as the Banda terrane is made up of volcanic and sedimentary sequences associated with the Sunda and Banda volcanic arcs that overlie a polyphase metamorphic complex (Audley-Charles \& Harris 1990). In contrast to the Banda terrane, the lower Australian Plate is made up of passive-margin rift-related sequences associated with the breakup of Gondwanaland beginning in the Permian (O’Brien et al. 1993; Harris et al. 1998). As there is no

\footnotetext{
*Appendix 1 [indicated by an asterisk $\left(^{*}\right)$ in the text and listed at the end of the paper] is a Supplementary Paper; copies may be obtained from the Geological Society of Australia's website (<www.gsa.org.au >) or from the National Library of Australia's Pandora archive (<http://nla.gov.au/nla.arc-25194>).

${ }^{\dagger}$ Corresponding author: trevor.falloon@utas.edu.au
} 
evidence for any active subduction beneath this margin, we would not expect to find any subduction zone geochemical features in peridotite bodies derived from the lower Australian Plate, as a result of Miocene collision. Harris and Long (2000) argued on the basis of major elements only that the Hili Manu peridotites were relatively fertile compared with refractory forearc peridotites (Parkinson \& Pearce 1998) and therefore most likely to be derived from the lower Australian Plate. In contrast, Berry (1981) argued the Hili Manu peridotite is a sample of the oceanic mantle trapped between the Java Trench and the Inner Banda Arc and hence is part of the upper Banda Plate. The aim of this report is to use the detailed trace-element and isotopic composition of the Hili Manu peridotite to resolve these conflicting interpretations.

\section{REGIONAL SETTING}

The island of Timor was formed by the Miocene collision between the northwest margin of the Australian continent and an island arc-subduction complex (Berry \& McDougall 1986). Timor is separated from the North West Shelf of Australia by a 3-km-deep trough that is underlain by crustal rocks characteristic of continental areas (Curray et al. 1977). Gravity modelling confirms that continental crust continues to the northern edge of Timor (Chamalaun et al. 1976). About $100 \mathrm{~km}$ north of Timor is a line of volcanic islands known as the inner Banda Arc. This arc is continuous with the volcanic chain through Java and Sumatra
(Sunda Arc) and has active andesitic volcanoes along most of its length, except north of Timor.

Timor is presently rising rapidly (Chappell \& Veeh 1978). The geological structure is dominated by strong faulting, and a large range of rock types occurs on the island, commonly as small, fault-bounded blocks. Many are similar to rocks of the same age on the continental shelf to the south, whereas others have been correlated with lithological associations found in Sundaland (Carter et al. 1976; Milsom 2000) or have been identified as abyssal sediments.

The steep gradient in the gravity field across Timor is due to the rapid transition from continental to oceanic crust (Chamalaun et al. 1976). In addition to this northsouth gradient, a local gravity high occurs $30 \mathrm{~km}$ east of Dili (Milsom \& Richardson 1976) centred on the Hili Manu peridotite. The extent of this anomaly suggests a substantial extension of ultramafic rocks at depth.

\section{GEOLOGY}

The Hili Manu peridotite body abuts a large block of amphibolite-facies schists, the Aileu Formation, along a near-vertical fault on its southern margin (Figure 1). To the east, there is also a small block of amphibolite of ambiguous association (Berry 1979; Harris \& Long 2000), but the nature of this eastern contact is unknown. Berry and McDougall (1986) suggested that this massive amphibolite could be correlated with the Aileu Formation, but recently Charleton (2002) interpreted the amphibolite as allochthonous.

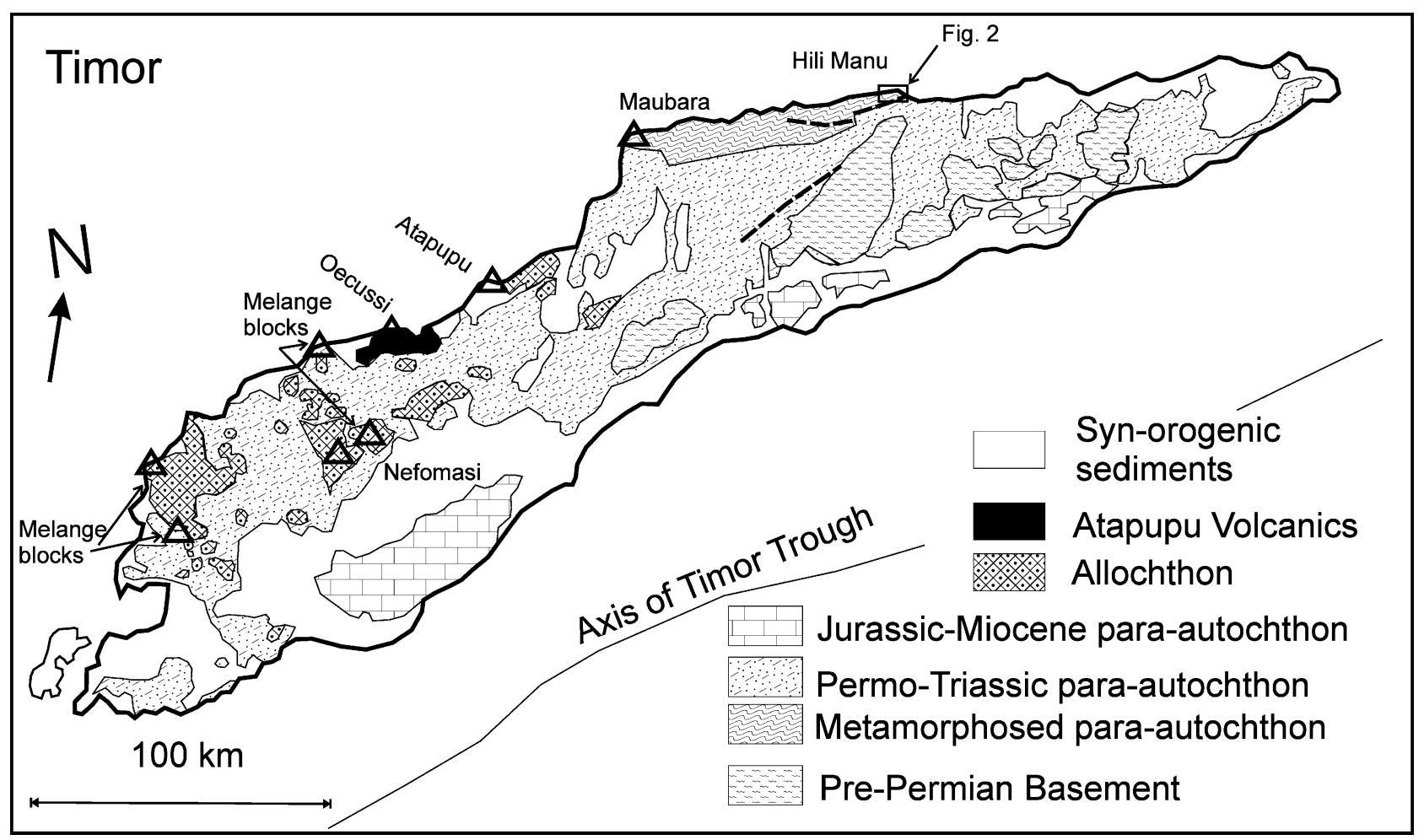

Figure 1 Location and field relationships of the Hili Manu peridotite, East Timor (geology slightly modified from Charlton 2002). 
The most common rock type of the Hili Manu peridotite body is a very fine-grained, brown-weathering lherzolite, in which orthopyroxene occurs as large, tabular porphyroclasts standing out on the weathered surface. A compositional layering, commonly $2-10 \mathrm{~cm}$ thick, is defined by concentrations of orthopyroxene. The layering dips at a moderate angle to the south. There is also a strong foliation subparallel to the layering, which is defined by the dimensional preferred orientation of the tabular orthopyroxene grains. In a few areas, the peridotite is altered to massive, pale-green or brown serpentinite.

For this project, we have reanalysed the original samples reported by Berry (1981). These samples have been moved to the University of Tasmania (UTAS) and are reported here with the new UTAS catalogue numbers.

\section{SAMPLE SELECTION AND ANALYTICAL METHODS}

The samples are the same as those of Berry (1981) and were collected from the peridotite where it crops out along the road and along the foreshore (Figure 2). Samples were ground in an agate mill to avoid any possible trace-element contamination. Some of the samples collected were from boulders along the foreshore. Major- and some trace-element analyses (Table 1) were performed at the School of Earth Sciences (UTAS) using X-ray fluorescence spectrometry (XRF) and the methods of Robinson (2003). Additional trace-element geochemistry (Table 2) was performed at the School of Earth Sciences and Central Science Laboratories (UTAS) using inductively coupled plasma-mass spectrometry (ICP-MS) and the methods of Robinson et al. (1999) and Yu et al. (2000). ICP-MS analyses were performed on duplicate high-pressure $\mathrm{HF}-\mathrm{HClO}_{4}$ digestions. Sub-boiling double-distilled

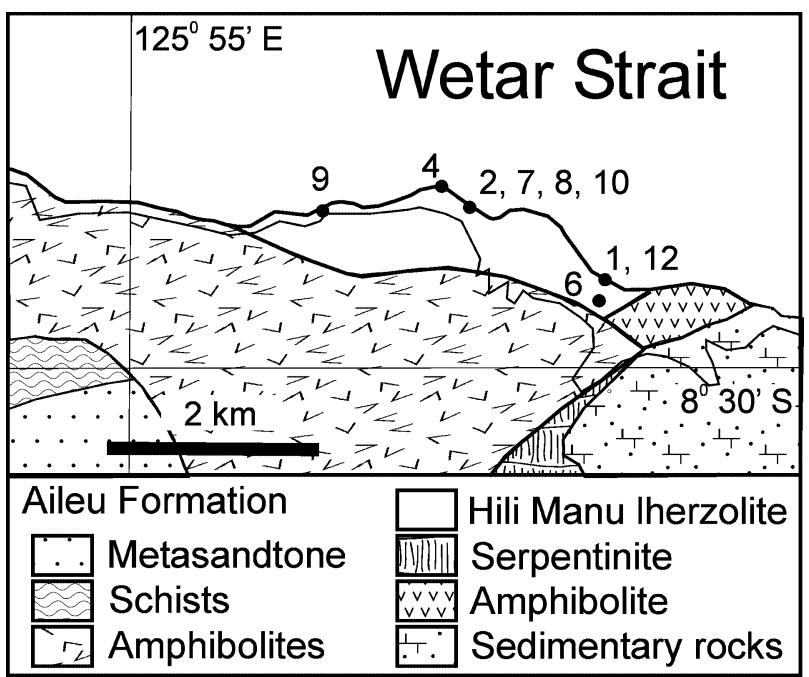

Figure 2 Sample locations of studied peridotite samples from the Hili Manu peridotite. Location of map shown on Figure 1. acids and ultra-pure water were used, as were clean sampler and skimmer cones, ICP torch, spray chamber, nebuliser and sample-introduction tubes (including auto-sampler tubing). Prior to sample analysis, the instrument was purged for at least $24 \mathrm{~h}$ with $5 \% \mathrm{v} / \mathrm{v}$ $\mathrm{HNO}_{3}$ and $0.05 \% \mathrm{v} / \mathrm{v}$ HF rinse solution. The international peridotite standard PCC-1 was also analysed along with the Hili Manu samples, and our results for this standard are compared with literature values in Appendix 1*. Isotope analyses (Table 3 ) were performed at the Max Planck-Institut für Chemie in Mainz by thermal ionisation mass spectrometry (TIMS) following methods outlined by Rampone et al. (1995). Both leached and unleached aliquots of whole-rock powders were analysed. Whole-rock powders were leached in hot $6 \mathrm{~N} \mathrm{HCl}$, and the residue was thoroughly washed in $\mathrm{H}_{2} \mathrm{O}$. During the period of analyses (1995), the La Jolla $\mathrm{Nd}$ standard and SRM-NBS $987 \mathrm{Sr}$ standards yielded ${ }^{143} \mathrm{Nd} /{ }^{144} \mathrm{Nd}=0.511859 \pm 11$ (five analyses) and ${ }^{87} \mathrm{Sr} /{ }^{86} \mathrm{Sr}=0.710266 \pm 14 \quad(10$ analyses $) . \mathrm{Rb}, \mathrm{Sr}, \mathrm{Sm}$ and $\mathrm{Nd}$ concentrations were determined by isotope dilution (ID).

\section{RESULTS}

\section{Major- and trace-element geochemistry}

The major- and trace-element geochemistry of the Hili Manu peridotite is presented in Tables 1 and 2 . Compared with peridotite bodies from alpine, ophiolitic and abyssal environments, the Hili Manu peridotite is exceptional in being relatively free from alteration. Our analysed Hili Manu peridotite samples have an average LOI of $0.04 \pm 0.29 \%$. In comparison, the abyssal peridotites reported by Niu (2004) are $>60$ vol\% serpentinised with LOI $>10 \%$. The geochemical variations observed in the Hili Manu peridotite can confidently be attributed to primary mantle processes of partial melting, and melt infiltration and impregnation. There is no evidence of mineralogical or chemical modification after the hightemperature mylonitic fabric was produced. Anhydrous $\mathrm{MgO}$ contents of the Hili Manu peridotite vary from 37 to $45 \mathrm{wt} \%$, and many major and trace elements display a strong correlation with $\mathrm{MgO}$ (Figure 3). Geochemical modelling and experimental studies on a model Hili Manu peridotite composition demonstrate that these correlations are consistent with partial melting processes in the mantle (T. J. Falloon \& R. F. Berry unpubl. data).

Many elements do not display good correlations with $\mathrm{MgO}$, especially the low rare-earth elements (LREE) and high field strength elements (HFSE) such as Nb and Ta. Chondrite normalised REE patterns for the Hili Manu samples are presented in Figure 4. Hili Manu lherzolite samples show LREE-depleted patterns $\left(\mathrm{La}_{\mathrm{N}} / \mathrm{Sm}_{\mathrm{N}}<1\right)$, whereas the harzburgites show LREE enrichment patterns $\left(\mathrm{La}_{N} / \mathrm{Sm}_{\mathrm{N}}>1\right)$. The REE contents of the Hili Manu peridotite, in common with other peridotite suites (Takazawa et al. 2000, 2003; Niu 2004), are inconsistent with a simple partial melting process and indicate that peridotite samples from the Hili Manu peridotite are not simple residues. 
Table 1 Whole-rock major- and trace-element geochemistry (XRF) and modal mineral abundances of the Hili Manu peridotite samples investigated in this study.

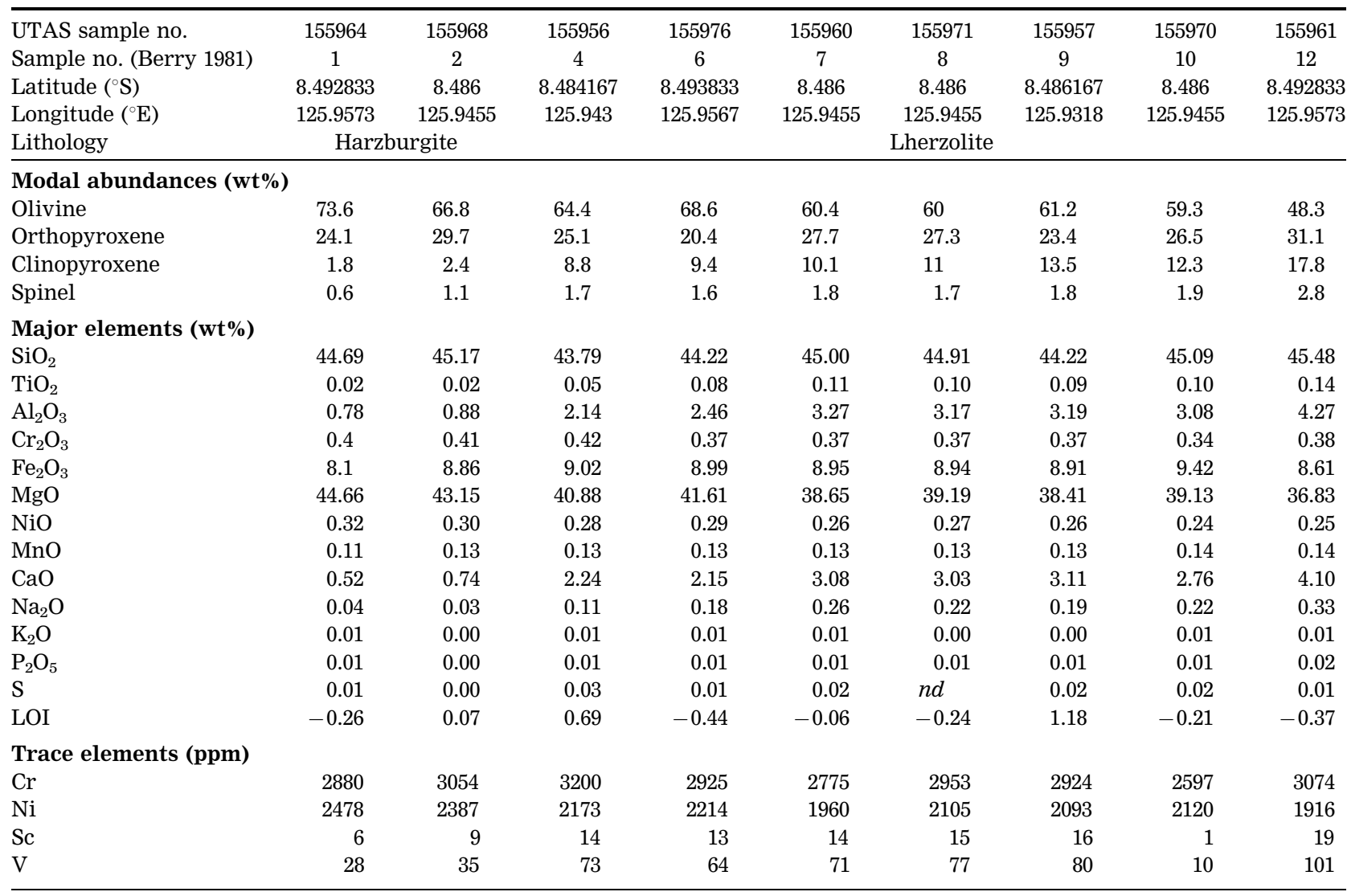

In Figure 5, we plot, in a similar manner to Niu (2004), the correlation coefficients $\left(R^{2}\right)$ of the REE with $\mathrm{MgO}$ and compare these with $R^{2}$ values from abyssal peridotite (Niu 2004) and the Horoman peridotite body (Takazawa et al. 2000). As can be seen from Figure 3, the $R^{2}$ values for the MREE to the HREE are all above 0.9 for the Hili Manu peridotite, and together these REE ( $\mathrm{Lu}$ through to Sm) show a distinct 'plateau'. This result indicates that the variations in HREE and MREE are consistent with partial melting (T. J. Falloon \& R. F. Berry unpubl. data), whereas the LREE (Nd through to La) are not. It can be seen from Figure 5 that the $R^{2}$ values for the LREE drop dramatically in a systematic manner for Hili Manu peridotite, indicating that another process or processes is required to explain their variation. A similar result is also evident for the Horoman peridotite (Figure 5). The REE patterns for harzburgites from Hili Manu are similar to refractory peridotites from other mantle suites which show U-shaped normalised REE patterns (Prinzhofer \& Allègre 1985; Jahn 1986; McDonough \& Frey 1989; Sharma \& Wasserburg 1996; Van der Wal \& Bodinier 1996; Gruau et al. 1998; Parkinson \& Pearce 1998; Godard et al. 2000; Takazawa et al. 2000, 2003; Girardeau et al. 2002; Niu 2004). The presence of U-shaped REE patterns in depleted residues suggests that they have been affected by an additional mantle process such as metasomatism or secondary fertilisation during the melt/rock reaction (Navon \& Stolper 1987; Bodinier et al. 1990; Kelemen et al. 1992; Takazawa et al. 1992; Godard et al. 2000; Niu 2004).

\section{Neodymium and strontium isotopic data}

The $\mathrm{Nd}$ and $\mathrm{Sr}$ isotopic results for the Hili Manu peridotite are presented in Table 3 and Figure 6. The samples have a large range in ${ }^{143} \mathrm{Nd} /{ }^{144} \mathrm{Nd}(0.51243-$ $0.51326)$ and ${ }^{87} \mathrm{Sr} /{ }^{86} \mathrm{Sr}(0.70312-0.70942)$ values. The lherzolite samples (except sample 155956) all have ${ }^{143} \mathrm{Nd} /{ }^{144} \mathrm{Nd}$ and ${ }^{87} \mathrm{Sr} /{ }^{86} \mathrm{Sr}$ values consistent with a depleted mantle source and fall within the range defined by natural glasses from Indian Ocean spreading centres. However, the two studied harzburgite samples have enriched ${ }^{143} \mathrm{Nd} /{ }^{144} \mathrm{Nd}$ and ${ }^{87} \mathrm{Sr} /{ }^{86} \mathrm{Sr}$ values, and fall within the range of volcanics from the Sunda-Banda Island Arc. The $\mathrm{Nd}$ and $\mathrm{Sr}$ isotopic values, in general, are poorly correlated with other major and trace elements and ratios. In particular, a poor correlation of ${ }^{143} \mathrm{Nd} /{ }^{144} \mathrm{Nd}$ with $\mathrm{Sm} / \mathrm{Nd}$ makes any calculation of model ages for the Hili Manu peridotite problematic (Rampone \& Piccardo 2000). The range in $\mathrm{Nd}$ and $\mathrm{Sr}$ isotopic values displayed by the Hili Manu peridotite emphasises again that they are not simple residues. The range in $\mathrm{Nd}$ and $\mathrm{Sr}$ values of the Hili Manu peridotite is most likely explained by the infiltration of migrating melts of distinctively different 
Table 2 Whole-rock trace-element geochemistry (ICPMS) of the Hili Manu peridotite samples investigated in this study.

\begin{tabular}{|c|c|c|c|c|c|c|c|c|c|}
\hline UTAS sample no. & 155964 & 155968 & 155956 & 155976 & 155960 & 155971 & 155957 & 155970 & 155961 \\
\hline \multicolumn{10}{|c|}{ Trace elements (ppm) } \\
\hline Sc & 4.6 & 9.5 & 13.4 & 13.6 & 16.7 & 16.6 & 16.4 & 16.2 & 19.6 \\
\hline $\mathrm{Rb}$ & 0.077 & 0.074 & 0.040 & 0.037 & 0.184 & 0.086 & 0.045 & 0.073 & 0.028 \\
\hline $\mathrm{Sr}$ & 0.309 & 1.549 & 0.614 & 2.123 & 2.622 & 1.751 & 1.195 & 2.262 & 2.324 \\
\hline Sn & 0.01 & 0.0304 & 0.0336 & 0.0662 & 0.0483 & 0.0237 & 0.0180 & 0.0394 & 0.3375 \\
\hline $\mathrm{Y}$ & 0.3489 & 0.2822 & 1.2616 & 1.7891 & 2.8025 & 2.7427 & 2.5308 & 2.4408 & 4.1902 \\
\hline $\mathrm{Zr}$ & 0.1251 & 0.2253 & 0.2547 & 2.0016 & 2.0804 & 2.1254 & 0.8272 & 2.2070 & 2.8760 \\
\hline $\mathrm{Nb}$ & 0.0300 & 0.0754 & 0.0190 & 0.0508 & 0.0824 & 0.0643 & 0.0246 & 0.0448 & 0.0191 \\
\hline Mo & 0.0396 & 0.1460 & 0.2618 & 0.1743 & 0.1295 & 0.1700 & 0.1600 & 0.2034 & 0.0758 \\
\hline $\mathrm{Ba}$ & 0.9408 & 0.5500 & 0.3000 & 0.2236 & 4.4978 & 0.5345 & 0.2979 & 0.4482 & 0.8003 \\
\hline $\mathrm{Sb}$ & 0.0914 & 0.0077 & 0.0797 & 0.0049 & 0.0170 & 0.0081 & 0.0144 & 0.0092 & 0.0072 \\
\hline $\mathrm{La}$ & 0.0342 & 0.0170 & 0.0088 & 0.0154 & 0.0611 & 0.0444 & 0.0072 & 0.0264 & 0.0195 \\
\hline $\mathrm{Ce}$ & 0.0535 & 0.0285 & 0.0168 & 0.1029 & 0.1701 & 0.1467 & 0.0296 & 0.1237 & 0.1315 \\
\hline $\mathrm{Pr}$ & 0.0051 & 0.0037 & 0.0056 & 0.0293 & 0.0370 & 0.0363 & 0.0154 & 0.0332 & 0.0461 \\
\hline $\mathrm{Nd}$ & 0.0190 & 0.0192 & 0.0512 & 0.2511 & 0.3104 & 0.3339 & 0.1758 & 0.2975 & 0.4521 \\
\hline $\mathrm{Sm}$ & 0.0050 & 0.0071 & 0.0473 & 0.1192 & 0.1666 & 0.1828 & 0.1338 & 0.1630 & 0.2512 \\
\hline $\mathrm{Eu}$ & 0.0017 & 0.0027 & 0.0225 & 0.0542 & 0.0718 & 0.0788 & 0.0591 & 0.0714 & 0.1147 \\
\hline $\mathrm{Gd}$ & 0.0098 & 0.0154 & 0.1108 & 0.1933 & 0.2996 & 0.3046 & 0.2549 & 0.2687 & 0.4467 \\
\hline $\mathrm{Tb}$ & 0.0030 & 0.0039 & 0.0258 & 0.0411 & 0.0613 & 0.0643 & 0.0561 & 0.0556 & 0.0935 \\
\hline Dy & 0.0315 & 0.0367 & 0.1976 & 0.2980 & 0.4579 & 0.4688 & 0.4101 & 0.4123 & 0.6849 \\
\hline Ho & 0.0086 & 0.0103 & 0.0461 & 0.0689 & 0.1033 & 0.1083 & 0.0926 & 0.0933 & 0.1525 \\
\hline Er & 0.0375 & 0.0383 & 0.1469 & 0.2192 & 0.3110 & 0.3332 & 0.2855 & 0.2924 & 0.4647 \\
\hline $\mathrm{Tm}$ & 0.0066 & 0.0069 & 0.0226 & 0.0331 & 0.0456 & 0.0503 & 0.0426 & 0.0441 & 0.0680 \\
\hline $\mathrm{Yb}$ & 0.0540 & 0.0589 & 0.1619 & 0.2334 & 0.3191 & 0.3494 & 0.3001 & 0.3123 & 0.4632 \\
\hline $\mathrm{Lu}$ & 0.0079 & 0.0108 & 0.0261 & 0.0373 & 0.0495 & 0.0554 & 0.0466 & 0.0495 & 0.0717 \\
\hline Hf & 0.0038 & 0.0082 & 0.0246 & 0.0967 & 0.1072 & 0.1333 & 0.0693 & 0.1161 & 0.1613 \\
\hline $\mathrm{Ta}$ & 0.0003 & 0.0022 & 0.0004 & 0.0008 & 0.0018 & 0.0025 & 0.0004 & 0.0009 & 0.0008 \\
\hline $\mathrm{Bi}$ & 0.0002 & 0.0004 & 0.0103 & 0.0018 & 0.0001 & 0.0004 & 0.0008 & 0.0014 & 0.0004 \\
\hline Th & 0.0200 & 0.0044 & 0.0016 & 0.0046 & 0.0116 & 0.1040 & 0.0015 & 0.0046 & 0.0010 \\
\hline $\mathrm{U}$ & 0.0482 & 0.0033 & 0.0007 & 0.0050 & 0.0028 & 0.0067 & 0.0008 & 0.0016 & 0.0005 \\
\hline
\end{tabular}

Table 3 Whole-rock isotope geochemistry of the Hili Manu peridotite samples investigated in this study.

\begin{tabular}{lclcccc}
\hline UTAS sample no. & $\mathrm{Sr}^{87} / \mathrm{Sr}^{86 \mathrm{a}}$ & $\mathrm{Sr}^{87} / \mathrm{Sr}^{86}$ & $\mathrm{Nd}^{143} / \mathrm{Nd}^{144}$ & $\mathrm{Rb}$ & $\mathrm{Sr}$ & $\mathrm{Nd}$ \\
\hline 155976 & 0.703841 & 0.70312 & 0.513258 & 0.04 & 2.17 & 0.244 \\
155960 & 0.704252 & 0.703488 & 0.513187 & 0.645 & 2.37 & 0.32 \\
155961 & 0.703595 & 0.703507 & 0.512975 & 0.106 & 2.28 & 0.322 \\
155970 & 0.705928 & 0.704806 & 0.512902 & - & 3.58 & 0.341 \\
155971 & 0.706369 & 0.70515 & 0.512957 & 0.077 & 1.11 & 0.1328 \\
155957 & 0.707736 & 0.705431 & 0.513119 & 0.126 & 1.19 & 0.164 \\
155956 & 0.708469 & 0.708348 & 0.512943 & 0.053 & 0.71 & 0.142 \\
155968 & 0.708868 & 0.708766 & 0.51247 & - & 2.54 & 0.057 \\
155964 & - & 0.709421 & 0.512434 & 0.103 & 1.6 & 0.067 \\
& & & & & 0.018 & 0.008 \\
\end{tabular}

$\mathrm{Rb}, \mathrm{Sr}, \mathrm{Nd}$ and $\mathrm{Sm}$ contents are in ppm determined by ID.

${ }^{a}$ Unleached powders.

isotopic composition which have reacted with the depleted peridotite. Many studies of peridotite bodies have demonstrated that the isotopic enrichments observed in some peridotites are directly related to proximity of sampling to melt channels. The former existence of melt channels is defined by either: (i) dunite bodies, with transitions to harzburgite and eventually lherzolite at greater distances (Quick 1981; Kelemen et al. 1992); or (ii) pyroxenite layers (Becker 1996). In the case of the Hili Manu peridotite, the harzburgites (which are the result of modally enriched bands of orthopyroxene) probably formed by melt channelling and reaction by a subduction-related siliceous melt composition (T. J. Falloon \& R. F. Berry unpubl. data).

\section{DISCUSSION}

\section{Comparison with other peridotite suites}

Harris and Long (2000), based on major elements, compared the geochemistry of Timor peridotites (Figure 1) with other peridotite suites including alpine peridotites, 

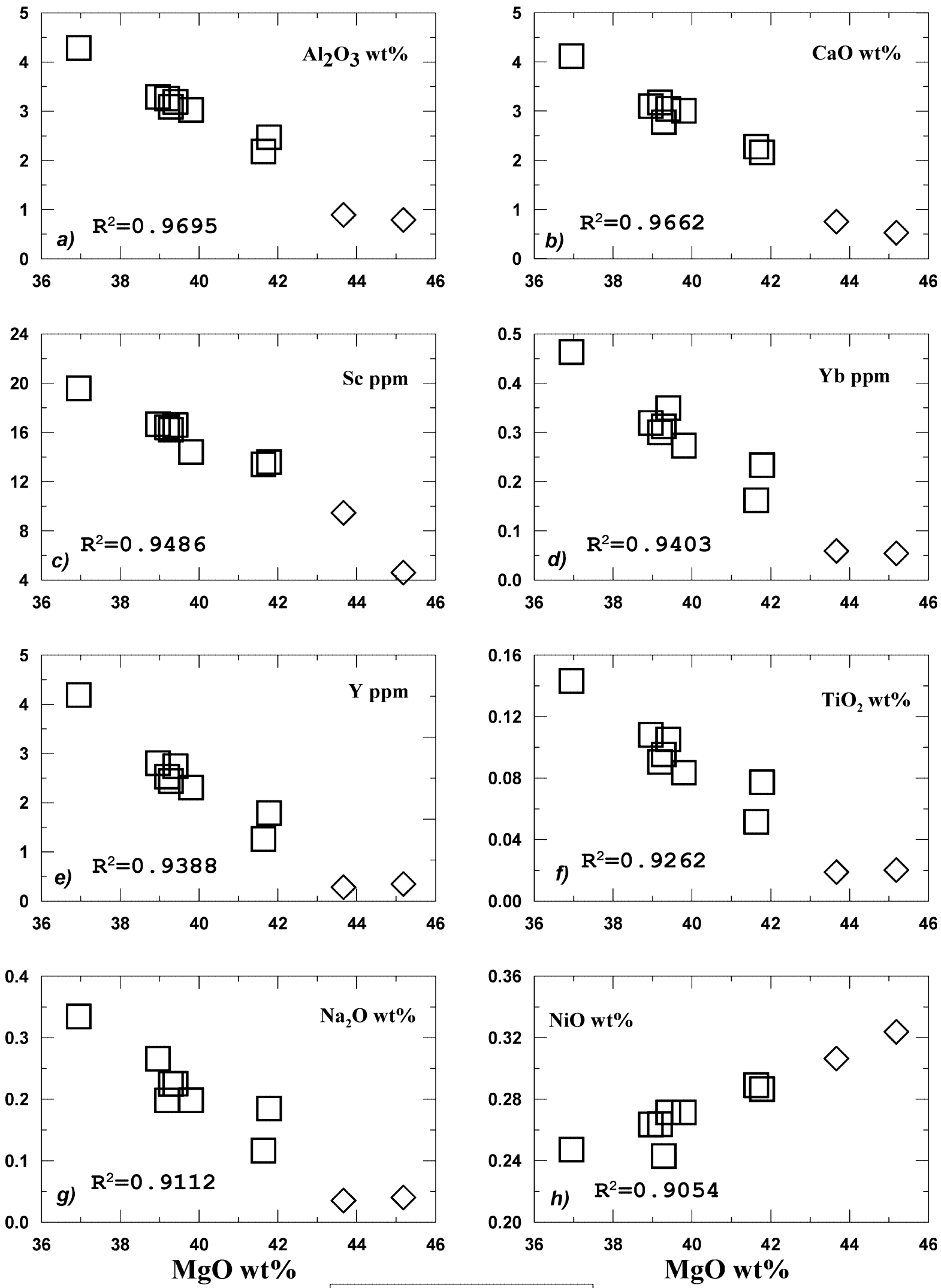

\section{Hili Manu Whole rocks \\ $\diamond \quad$ Harzburgites \\ Lherzolites}

Figure 3 Selected major and trace elements plotted against $\mathrm{MgO} \mathrm{wt} \%$ for samples from the Hili Manu peridotite. $R^{2}$ values were determined by least-squares linear regression. 


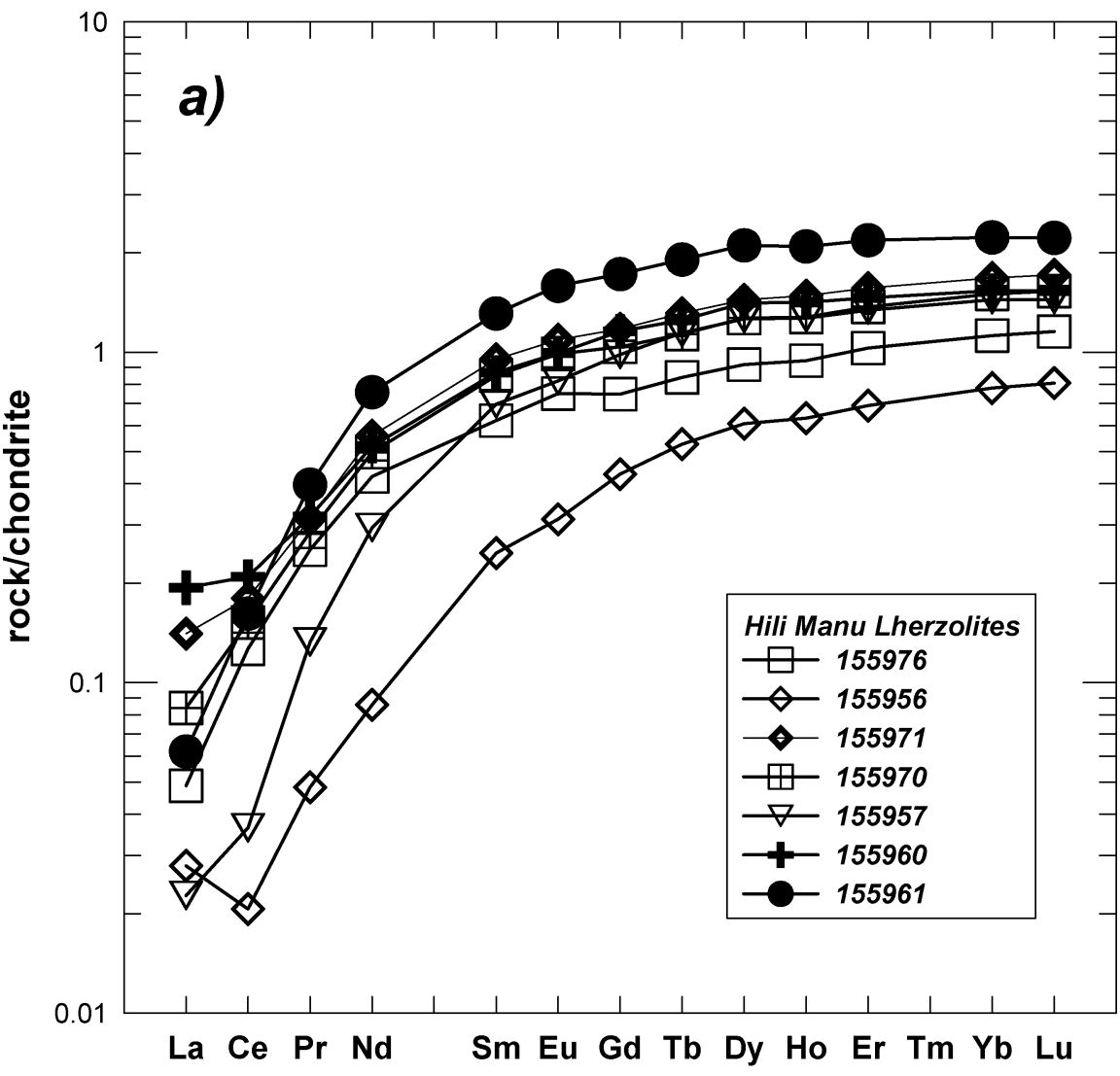

Figure 4 Chondrite-normalised REE patterns for (a) lherzolites and (b) harzburgites for the Hili Manu peridotite.

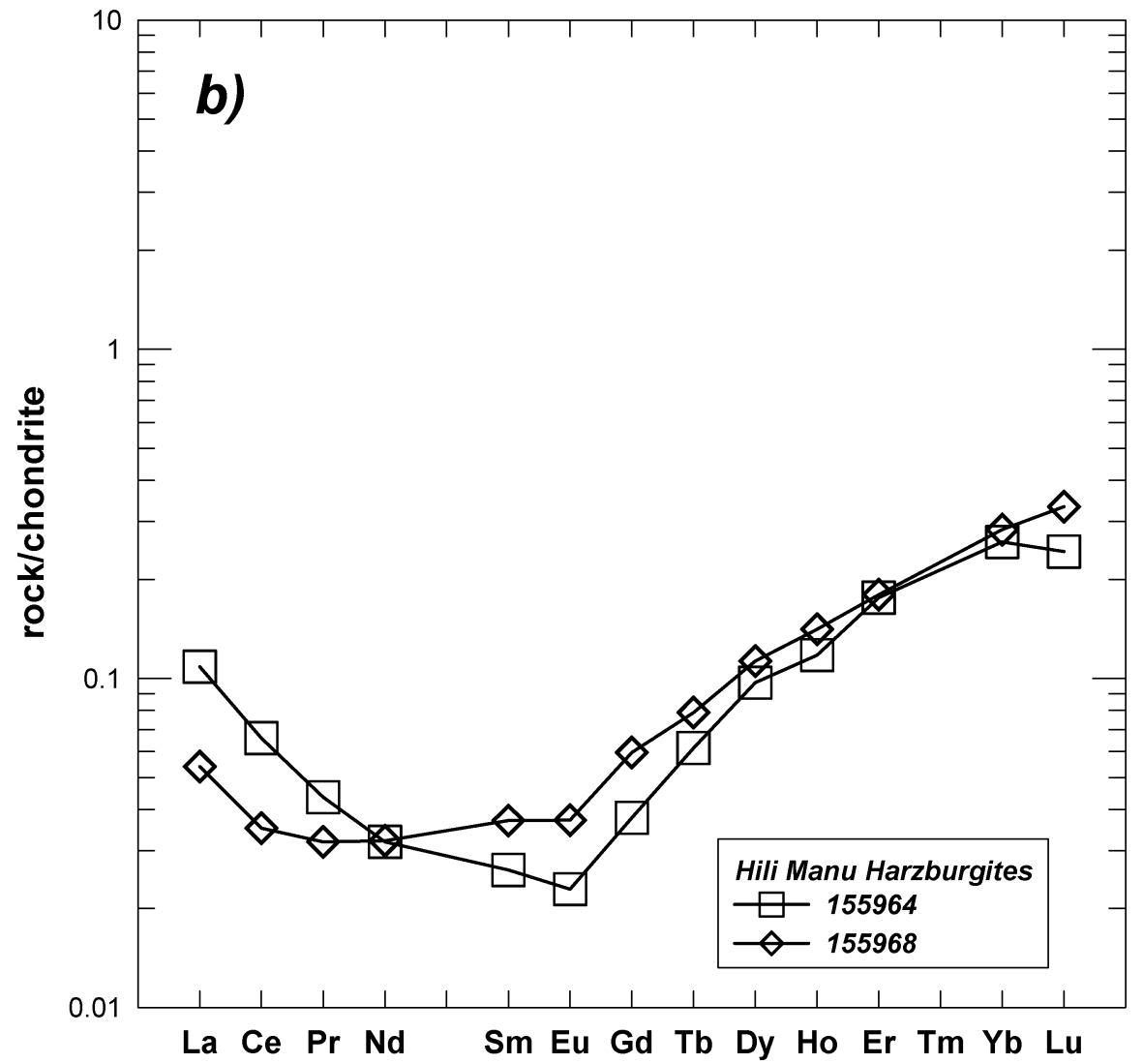

abyssal peridotites and supra-subduction-related peridotites from modern forearcs and trenches. On the basis of this comparison, they noted that the Timor peridotites including Hili Manu have compositions consistent with undepleted to slightly depleted continental lithosphere similar to many alpine peridotite bodies (e.g. Ronda, Horomann). On the basis of this and other arguments, Harris and Long (2000) concluded that the 

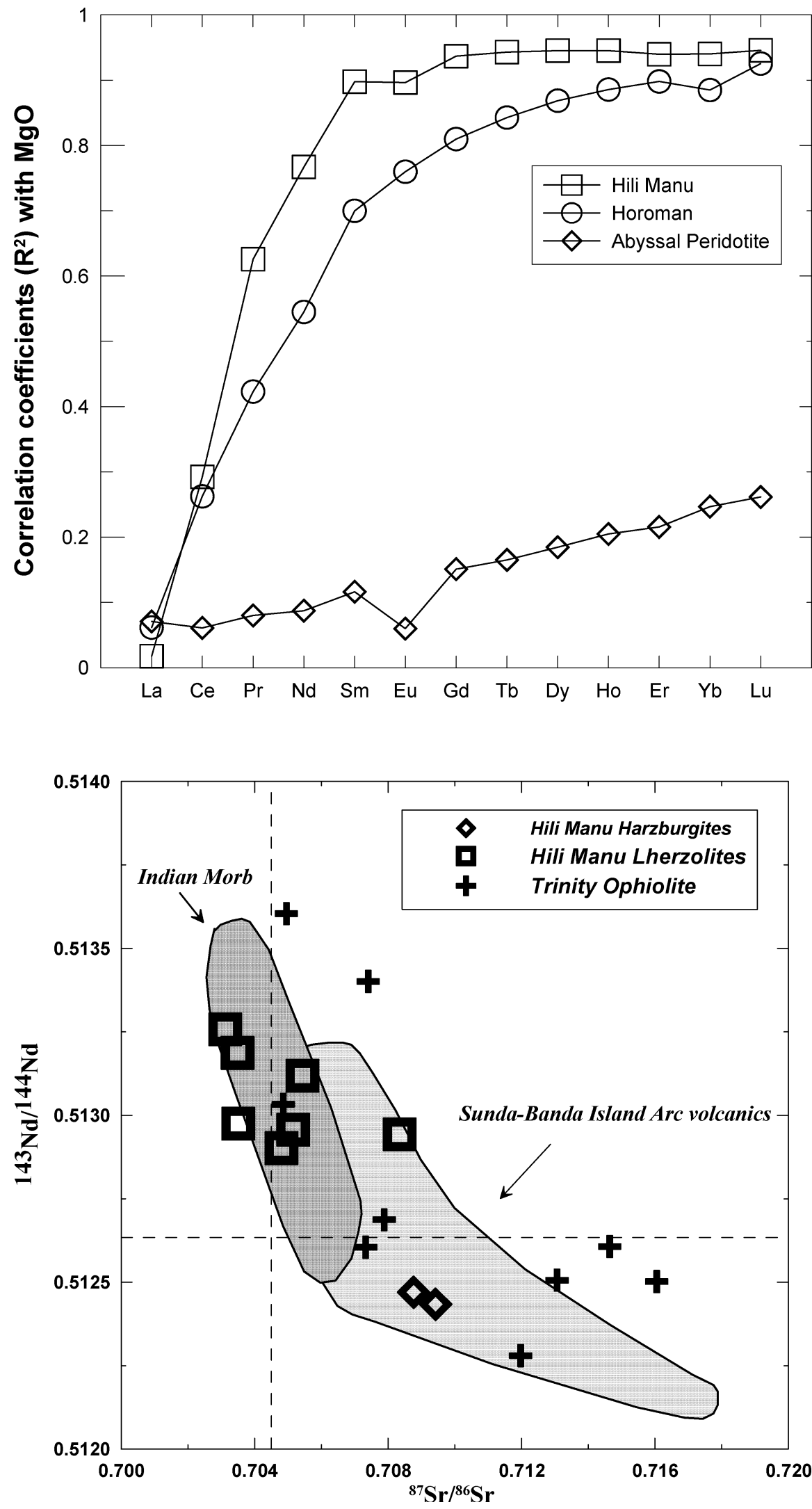

Figure 5 Correlation of REE elements with $\mathrm{MgO}$ wt\% for the Hili Manu peridotite and a comparison with the same correlations obtained for the Horoman peridotite body (Takazawa et al. 2000) and abyssal peridotites (Niu 2004).

Figure $6 \mathrm{Nd}$ and $\mathrm{Sr}$ isotopic composition of Hili Manu peridotite samples compared with glasses from Indian Ocean spreading centres, Sunda-Banda Island Arc volcanics, and peridotites from the Trinity ophiolite (Gruau et al. 1998). Data source for Indian Ocean MORB glass data (http:// petdb.ldeo.columbia.edu/petdb/ query.asp); for Sunda-Banda Island Arc volcanics (http:// georoc.mpch-mainz.gwdg.de/ georoc/).

Timor peridotite bodies were derived from Australian subcontinental lithosphere and exhumed during collision. The only exception to this conclusion is the Ocussi peridotite body (Figure 1) which has a very refractory major-element composition similar to peridotites from supra-subduction settings. The Ocussi peridotite body is also associated with volcanic rocks that have clear island-arc basalt affinities (Harris 1992). Therefore, at least one Timor peridotite body is clearly related to the Banda arc upper plate of the collision 
zone. The question is whether any of the other Timor peridotite bodies have a supra-subduction zone geochemical signature.

The Hili Manu peridotite, as discussed by Berry (1981) and Harris and Long (2000), has a range in majorelement composition intermediate between fertile, relatively undepleted, continental peridotite bodies and more-refractory abyssal peridotites. The geochemistry of the Hili Manu peridotite suggests that it is not a simple partial melting residue and that it has undergone some other additional processes to produce the U-shaped REE patterns in the most depleted harzburgites, and the range in $\mathrm{Nd}$ and $\mathrm{Sr}$ isotope compositions. We argued above that similar features are displayed by peridotite bodies from ophiolites which have a clear suprasubduction setting.

Supra-subduction zone ophiolites form two broad groups in terms of their structure, tectonics and magmatic features (Moores et al. 2000; Beccaluva et al. 2004). 'Tethyan' complexes (e.g. the Oman ophiolite) consist of complete and extensive volcanic, dyke, plutonic and mantle sections that have been obducted as relatively intact slabs onto passive continental margins during collisions (Beccaluva et al. 2004). 'Cordilleran' complexes (e.g. the Trinity ophiolite) mostly represent dismembered sections of arc volcanic, plutonic and mantle sequences associated with metamorphic rocks and tectonically emplaced, often with no

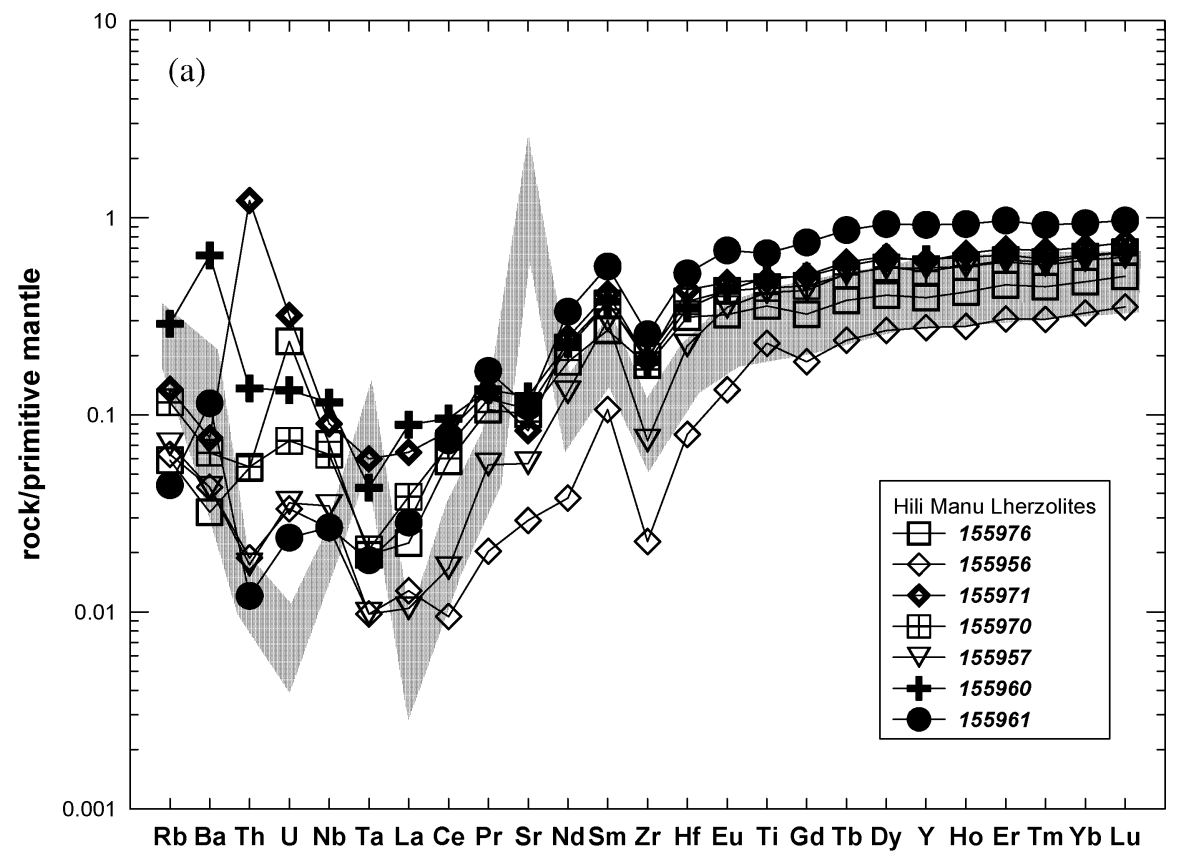

Figure 7 Primitive mantle-normalised abundance patterns for Hili Manu lherzolites (a) and harzburgites (b). Shaded field in (a) is the range in values for Type II lherzolites from Oman (Takazawa et al. 2003), and in (b) the range in values for harzburgites from the Western Zone of the Wuqbah peridotite, Oman (Girardeau et al. 2002). Normalising values for primitive mantle are from Sun and McDonough (1989).

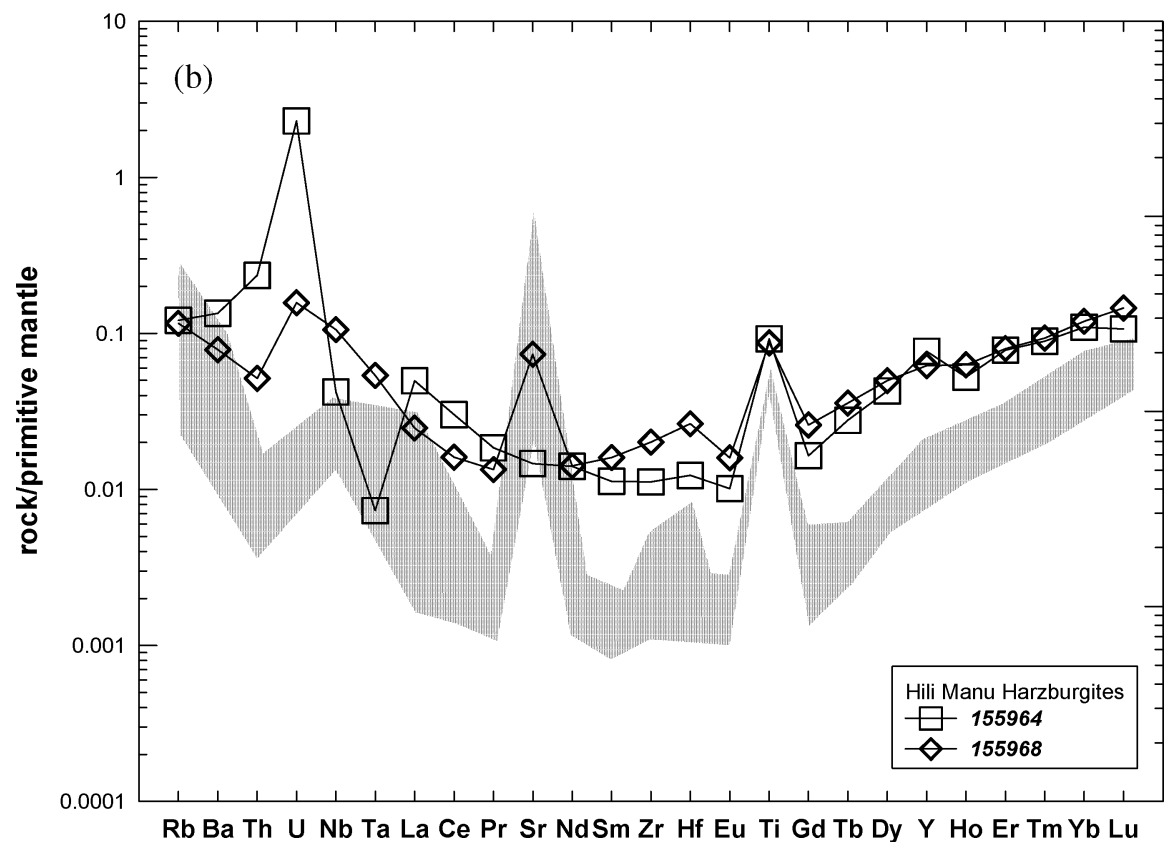


clear relationships, onto or against a collisional continental margin (Beccaluva et al. 2004). The Oman ophiolite has a clear subduction zone influence, reflected in the chemistry of its associated lavas (Pearce et al. 1981), but the scale of the ophiolite is such that it records many features characteristic of major midocean ridge spreading centres (MacLeod \& Rothery 1992). In contrast, the dismembered Trinity ophiolite is a polygenetic supra-subduction zone ophiolite that formed in a trench-proximal extensional environment (Brouxel \& Lapierre 1988; Metcalf et al. 2000).

The peridotite from the Trinity ophiolite (Figure 6) shows a range in $\mathrm{Nd}$ and $\mathrm{Sr}$ isotopic compositions even more extreme than the Hili Manu peridotite (Gruau et al. 1998). In the case of the Oman ophiolite, Sharma and Wasserburg (1996) reported a very enriched ${ }^{143} \mathrm{Nd} /{ }^{144} \mathrm{Nd}$ value of 0.511997 for a harzburgite with a U-shaped normalised REE pattern. As can be seen from Figure 7, the trace-element-normalised abundance patterns of lherzolite and harzburgite samples from the Hili Manu peridotite are very close to similar lithologies from the Oman ophiolite (Godard et al. 2000; Girardeau et al. 2002; Takazawa et al. 2003). These comparisons are interpreted here as evidence that the Hili Manu peridotite was derived from a supra-subduction zone setting rather than a continental setting.

Gruau et al. (1998) reported a detailed study of peridotites from the Trinity ophiolite. They argued on the basis of oxygen, carbon and hydrogen stable-isotope values in serpentinised peridotites that the enrichment in LREE and isotopic values of the Trinity ophiolite was more likely to be related to a late-stage crustal-derived fluid that had pervaded the peridotite protolith during emplacement onto the North American continental margin. The alternative hypothesis is that the enrichment in LREE and isotope values occurred through a high-temperature interaction of melts/fluids derived from a subducted crust when the peridotite protolith was located in a supra-subduction setting.

One possible way to distinguish between these two models is to consider the variation of $\mathrm{Nb}$, $\mathrm{Ta}, \mathrm{Zr}$ and $\mathrm{Hf}$. Experimental data on partitioning of HFSE between solid and fluids indicate that fluids derived from a slab or a continental source are unlikely to carry significant HFSE (Brenan et al. 1994; Stolz et al. 1996; Audétat \& Keppler 2005; Kessel et al. 2005; Tropper \& Manning 2005). In contrast, experimental studies demonstrate that these ratios can be fractionated by solid/melt equilibria (Foley et al. 1999; Green et al. 2000; Tiepolo et al. 2000). Thus, any changes in $\mathrm{Nb} / \mathrm{Ta}$ or $\mathrm{Zr} / \mathrm{Hf}$ ratios must be attributed to addition or removal from a melt. In Figure 8 , the $\mathrm{Nb} / \mathrm{Ta}$ and $\mathrm{Zr} / \mathrm{Hf}$ values of the Hili Manu samples are plotted with whole-rock peridotite values from alpine (Balumucci, Ronda, Horoman) and abyssal peridotites, and supra-subduction peridotites (Oman ophiolite, Tongan Forearc-Trench).

Experimental studies combined with studies of terrestrial rocks (Godard et al. 2000; Rudnick et al. 2000; Takazawa et al. 2000; Weyer et al. 2002, 2003) suggest that the bulk distribution coefficients between solid/melt are in the following order $D_{\mathrm{Nb}}<D_{\mathrm{Ta}}$ and $D_{\mathrm{Zr}}$ $<D_{\mathrm{Hf}}$. Therefore, partial melts will have super-chondritic ratios (chondritic $\mathrm{Zr} / \mathrm{Hf} \sim 36.3$ and $\mathrm{Nb} / \mathrm{Ta}$ $\sim 17.57$ ), but residues will be highly depleted in $\mathrm{Nb}, \mathrm{Ta}$, $\mathrm{Zr}$ and $\mathrm{Hf}$ with substantially sub-chondritic $\mathrm{Nb} / \mathrm{Ta}$ and $\mathrm{Zr} / \mathrm{Hf}$ ratios. The predicted trends for residues and melts are shown on Figure 8. The process of melting combined with subsequent melt/rock reaction best explains the range in $\mathrm{Zr} / \mathrm{Hf}$ and $\mathrm{Nb} / \mathrm{Ta}$ values in both alpine and abyssal peridotites (Weyer et al. 2003; Takazawa et al. 2003; Niu 2004). Although peridotites from Hili Manu, Oman and Tongan Forearc-Trench samples have all undergone partial melting and melt/ rock reactions, their relatively high $\mathrm{Nb} / \mathrm{Ta}$ ratios

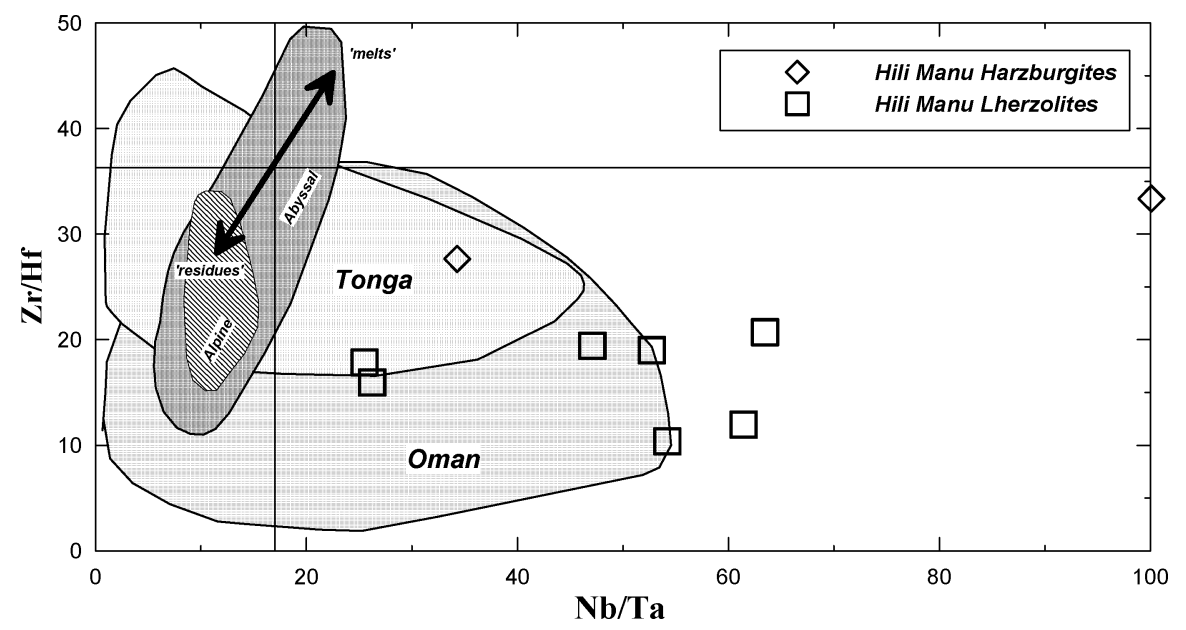

Figure 8 Variation in $\mathrm{Nb} / \mathrm{Ta}$ and $\mathrm{Zr} / \mathrm{Hf}$ values in the Hili Manu peridotite compared with values from abyssal peridotites [field encompasses average values for the following fracture zone samples: Udinstev, Vulcan, Islas Orcadas, Prince Edward, Atlantis II, Andrew Basin, Garrett, Bullard, Discovery, Central Indian Ridge (Niu 2004); and Hess Deep (T. J. Falloon unpubl. data)], alpine peridotites [field encompasses the average values for the following bodies: Balmuccia (Weyer et al. 2003), Horoman (Takazawa et al. 2000) and Ronda (Lenoir et al. 2001)], the Oman ophiolite (Godard et al. 2000; Takazawa et al. 2003) and peridotites from the Tonga Forearc-Trench (T. J. Falloon unpubl. data). Straight lines delineate chondritic values. Arrows indicate the expected trend for residues and melts during mantle-melting processes (see text for further explanation). 
suggest that the melt/rock reaction process involved a melt composition distinct from that which was involved in the petrogenesis of alpine and abyssal peridotite protoliths. Stolz et al. (1996) suggested that high $\mathrm{Nb} / \mathrm{Ta}$ ratios are produced by partial melts of subducted oceanic crust/subducted sediment. Therefore, the high $\mathrm{Nb} / \mathrm{Ta}$ ratios of the Hili Manu peridotite are consistent with a supra-subduction origin for the original peridotite protolith, which was subsequently faulted against the Australian continental margin.

\section{CONCLUSIONS AND IMPLICATIONS FOR TIMOR PERIDOTITES}

Most models for the tectonic evolution of the Outer Banda Arc interpret peridotite bodies on Timor, such as Hili Manu peridotite, as fragments of oceanic lithosphere derived from forearc (Hamilton 1979; Sopaheluwakan et al. 1989). However, Harris and Long (2000), using major-element geochemistry, considered most of these peridotite bodies to be derived from the Australian subcontinental lithosphere and that no Oman-style ophiolite emplacement took place. Our geochemical study of the Hili Manu peridotite body supports the model that the peridotite bodies associated with the outer Banda Arc represent pieces of oceanic lithosphere from a supra-subduction setting from either a forearc or backarc position. In particular, the $\mathrm{Nd}$ and $\mathrm{Sr}$ isotopic composition and HFSE ratios such as $\mathrm{Nb} / \mathrm{Ta}$ indicate that the Hili Manu peridotite was not derived from a continental or mid-ocean ridge environment. This result, along with the clear supra-subduction setting of the Ocuzzi peridotite and associated volcanics in West Timor, gives support to the model that the Miocene collision between the Banda Arc and the Australian continental margin is an analogue for 'Cordilleran'-style ophiolites and their emplacement (Beccaluva et al. 2004).

\section{ACKNOWLEDGEMENTS}

AJS gratefully acknowledges support from the Alexander von Humbodlt Stiftung during the course of this study. We thank Zongshou Yu, Ashley Townsend, Katie McGoldrick and Nilar Hlaing, for help with sample preparation and XRF and ICPMS analysis. We also thank Marc Norman and Simon Turner, for their constructive reviews.

\section{REFERENCES}

AudÉtAT A. \& KePPler H. 2005. Solubility of rutile in subduction zone fluids, as determined by experiments in the hydrothermal diamond anvil cell. Earth and Planetary Science Letters 232, $393-402$.

AUDLEY-CHARLES M. G. \& HARRIS R. A. 1990. Allochthonous terranes of the South-west Pacific and Indonesia. Philosophical Transactions of the Royal Society of London 331, 571-587.

Beccaluva L., Coltorti M., Giunta G. \& Siena F. 2004. Tethyan vs Cordilleran ophiolites: a reappraisal of distinctive tectonomagmatic features of supra-subduction complexes in relation to the subduction mode. Tectonophysics 393, 163-174.
BECKER H. 1996. Geochemistry of garnet peridotite massifs from lower Austria and the composition of deep lithosphere beneath a Palaeozoic convergent plate margin. Chemical Geology 134, $49-65$.

BERRY R. F. 1979. Deformation and metamorphism of the Aileu Formation, East Timor. PhD thesis, Flinders University, Adelaide (unpubl.).

BERRY R. F. 1981. Petrology of the Hili Manu lherzolite, East Timor. Journal of the Geological Society of Australia 28, 453-469.

BERRY R. F. \& MCDOUGALL I. 1986. Interpretation of ${ }^{40} \mathrm{Ar} /{ }^{39} \mathrm{Ar}$ and $\mathrm{K} / \mathrm{Ar}$ dating evidence from the Aileu Formation, East Timor, Indonesia. Chemical Geology 59, 43-59.

Bodinier J-L., VASSEUR G., VERniÈRES J., Dupuy C. \& FABRIÈs J. 1990. Mechanisms of mantle metasomatism: geochemical evidence from Lherz orogenic peridotite. Journal of Petrology 31, 597-628.

Brenan J. M., ShaW H. F., PhinNey D. L. \& Ryerson F. J. 1994. Rutile-aqueous fluid partitioning of $\mathrm{Nb}, \mathrm{Ta}, \mathrm{Hf}, \mathrm{Zr}, \mathrm{U}$ and $\mathrm{Th}$ : implications for high field strength element depletions in islandarc basalts. Earth and Planetary Science Letters 128, 327-339.

BROUXEL M. \& LAPIERRE H. 1988. Geochemical study of an early Paleozoic island arc-back arc basin system. I: The Trinity Ophiolite (Northern California). Geological Society of America Bulletin 100, 1111-1119.

Carignan J., Hild P., Mevelle G., Morel J. \& Yeghicheyan D. 2001. Routine analyses of trace elements in geological samples using flow injection and low pressure on-line liquid chromatography coupled to ICP-MS:A study of geochemical reference materials BR, DR-N, UB-N, AN-G and GH. Geostandards Newsletter 25 $187-198$.

Carter D. J., Audley-Charles M. G. \& Barber A. J. 1976. Stratigraphical analysis of island arc-continental margin collision in eastern Indonesia. Journal of the Geological Society of London 132, 179-198.

Chamalaun F. H., Lockwood K. \& White A. 1976. The Bouguer gravity field and crustal structure of eastern Timor. Tectonophysics 30, 241-259.

CHAPPELL J. \& VeEH H. H. 1978. Late Quaternary tectonic movements and sea-level changes at Timor and Atauro Island. Geological Society of America Bulletin 89, 356-368.

CHARLton T. R. 2002. The structural setting and tectonic significance of the Lolotoi, Laclubar and Aileu metamorphic massifs, East Timor. Journal of Asian Earth Sciences 20, 851-865.

ColEMAN R. G. 1971. Plate tectonic emplacement of upper mantle peridotite along continental edges. Journal of Geophysical Research 76, 1212-1222.

Curray J. R., Shor G. G., Rait R. W. \& Henry M. 1977. Seismic refraction and reflection studies of the crustal structure of eastern Sunda and Western Banda Arcs. Journal of Geophysical Research 82, 2479-2481.

DileK Y., Moores E. M., Elthon D. \& Nicolas A. 2000. Ophiolites and Oceanic Crust: New Insights from Field Studies and the Ocean Drilling Program. Geological Society of America Special Paper 349.

DULSKI P. 2001. Reference materials for geochemical studies: new analytical data by ICP-MS and critical discussion of reference values. Geostandards Newsletter 25, 87-126.

EGGINS S. M. 2003. Laser ablation ICP-MS analysis of geological materials prepared as lithium borate glasses. Geostandards Newsletter 27, 147-162.

Eggins S. M., Woodhead J. D., Kingsley L. P. J., Mortimer G. E., Sylvester P., McCulloch M. T., HeRgT J. M. \& HANDLER M. R. 1997. A simple method for the precise determination of $\geq 40$ trace elements in geological samples by ICPMS using enriched isotope internal standardisation. Chemical Geology 134, 311-326.

Foley S. F., Matthias G. B. \& Jenner G. A. 1999. Rutile/melt partition coefficients for trace elements and an assessment of the influence of rutile on the trace element characteristics of subduction zone magmas. Geochimica et Cosmochimica Acta 64, 933-938.

Girardeau J., Monnier C., Lemée L. \& Quatrevaux F. 2002. The Wuqbah peridotite, central Oman ophiolite: petrological characteristics of the mantle in a fossil overlapping ridge setting. Marine Geophysical Researches 23, 43-56.

GODARD M., JOUSSELIN D. \& BODINIER J.-L. 2000. Relationships between geochemistry and structure beneath a palaeo-spreading centre: a study of the mantle section in the Oman ophiolite. Earth and Planetary Science Letters 180, 133-148. 
GOVINDARAJU K. 1994. 1994 compilation of working values and sample descriptions for 383 geostandards. Geostandards Newsletter 18 (Special Issue), 1-158.

Green T. H., Blundy J. D., AdAm A. \& YaXley G. M. 2000. SIMS determination of trace element partition coefficients between garnet, clinopyroxene and hydrous basaltic liquids at 2-7.5 GPa and $1080-1200^{\circ} \mathrm{C}$. Lithos 53, $165-187$.

GRUAU G., BERNARD-GRIFFITHS J. \& LÉCUYER C. 1998. The origin of U-shaped rare earth patterns in ophiolite peridotites: assessing the role of secondary alteration and melt/rock reaction. Geochimica et Cosmochimica Acta 62, 3545-3560.

HAMILTON W. 1979. Tectonics of the Indonesian region. US Geological Survey Professional Paper 1078.

HARRIS R. A. 1992. Peri-collisional extension and the formation of Oman-type ophiolites in the Banda Arc and Brooks Range. In: Parson L. M., Murton B. J. \& Browning P. eds. Ophiolites and Their Modern Oceanic Analogues, pp. 301-325. Geological Society of London Special Publication 60.

HARRIS R. \& LONG T. 2000. The Timor ophiolite, Indonesia: Model or myth? In: Dilek Y., Moores E. M., Elthon D. \& Nicolas A. eds. Ophiolites and Oceanic Crust: New Insights from Field Studies and the Ocean Drilling Program, pp. 321-330. Geological Society of America Special Paper 349.

HARRis R. A., SAwyer R. K. \& Audley-Charles M. G. 1998. Collisional melange development: geologic associations of active melange-forming processes with exhumed melange facies in the western Banda orogen, Indonesia. Tectonics 17, 458-480.

Ionov D. A., SAvoyanT L. \& DuPUY C. 1992. Application of the ICPMS technique to trace element analysis of peridotites and their minerals. Geostandards Newsletter 16, 311-315.

JAHN B-M. 1986. Mid-ocean ridge or marginal basin origin of the East Taiwan ophiolite: chemical and isotopic evidence. Contributions to Mineralogy and Petrology 92, 194-206.

Jain J. C., Field M. P., NeAl C. R., Ely J. C. \& SherRell R. M. 2000. Determination of the REE in geological reference materials DTS1 (dunite) and PCC-1 (peridotite) by ultrasonic and microconcentric desolvating nebulisation ICP-MS. Geostandards Newsletter 24, 65-72.

JOCHUM K. P., SEIFERT H. M. \& THIRLWALL M. F. 1990. High-sensitivity $\mathrm{Nb}$ analysis by spark-source mass spectrometry (SSMS) and calibration of XRF Nb and Zr. Chemical Geology 81, 1-16.

Jochum K. P., Stoll B., Pfander J. A., Seufert H. M., Flanz M., MAISSENBACHER P. \& HoFmANN M. 2001. Progress in multi-ion counting spark-source mass spectrometry (MIC-SSMS) for the analysis of geological samples. Fresenius' Journal of Analytical Chemistry 370, 647-653.

Kelemen P. B., Dick H. J. B. \& QUick J. E. 1992. Formation of harzburgite by pervasive melt/rock reaction in the upper mantle. Nature 358, 635-641.

Kessel R., Schmidt M. W., Ulmer P. \& PettKe T. 2005. Trace element signature of subduction-zone fluids, melts and supercritical liquids at $120-180 \mathrm{~km}$ depth. Nature $437,724-727$.

LeNoIR X., GARRIDO C. J., Bodiniere J.-L., DAUtRIA J.-L. \& GERVILLA F. 2001. The recrystallization front of the Ronda Peridotite: evidence for melting and thermal erosion of subcontinental lithospheric mantle beneath the Alboran Basin. Journal of Petrology 42, 141-158.

MACLEOD C. J. \& ROTHERY D. A. 1992. Ridge axial segmentation in the Oman ophiolite: evidence from along-strike variations in the sheeted dyke complex. In: Parson L. M., Murton B. J. \& Browning P. eds. Ophiolites and Their Modern Oceanic Analogues, pp. 39-63. Geological Society of London Special Publication 60.

MAKISHIMA A., KoBAYASHI K. \& NAKAMURA E. 2002. Determination of chromium, nickel, copper and zinc in milligram samples of geological materials using isotope dilution high resolution inductively coupled plasma-mass spectrometry. Geostandards Newsletter 26, 41-51.

MAKISHIMA A. \& NAKAMURA E. 1997. Suppression of matrix effects in ICP-MS by high power operation of ICP: application to precise determination of $\mathrm{Rb}, \mathrm{Sr}, \mathrm{Y}, \mathrm{Cs}, \mathrm{Ba}, \mathrm{REE}, \mathrm{Pb}$, Th and $\mathrm{U}$ at $\mathrm{ng} \mathrm{g}^{-1}$ levels in milligram silicate samples. Geostandards Newsletter 21, 307-319.

MAKISHIMA A. \& NAKAMURA E. 1999. Determination of molybdenum, antimony and tungsten at sub $\mu \mathrm{g} \mathrm{g}^{-1}$ levels in geological materials by ID-FI-ICP-MS. Geostandards Newsletter 23, 137148.
MAKISHIMA A., NAKAMURA E. \& NAKANO T. 1999. Determination of zirconium, niobium, hafnium an tantalum at $\mathrm{ng}^{-1}$ levels in geological materials by direct nebulisation of sample $\mathrm{HF}$ solutions into FI-ICP-MS. Geostandards Newsletter 23, 7-20.

MCDONOUGH W. F. \& FREY F. A. 1989. Rare earth elements in upper mantle rocks. In: Lipin B. R. \& McKay G. A. eds. Geochemistry and Mineralogy of Rare Earth Elements, pp. 99-145. Reviews in Mineralogy 21.

Metcalf R. V., WAllin E. T., Willse K. R. \& Muller E. R. 2000. Geology and geochemistry of the ophiolitic Trinity terrane, California: evidence of middle Paleozoic depleted suprasubduction zone magmatism in a proto-arc setting. In: Dilek Y., Moores E. M., Elthon D. \& Nicolas A. eds. Ophiolites and Oceanic Crust: New Insights from Field Studies and the Ocean Drilling Program, pp. 403-418. Geological Society of America Special Paper 349.

MiLsom J. 2000. Stratigraphic constraints on suture models for eastern Indonesia. Journal of Asian Earth Sciences 18, 761-779.

MiLsOM J. \& RICHARDSON A. 1976. Implications of the occurrence of large gravity gradients in Northern Timor. Geologie en Mijnbouw 55, 175-178.

Minowa H. \& EBIHARA M. 2003. Separation of rare earth elements from scandium by extraction chromatography. Application to radiochemical neutron activation analysis for trace rare earth elements in geological samples. Analytica Chimica Acta 48, $25-37$.

Moores E. M., Kellog L. H. \& DileK Y. 2000. Tethyan ophiolites, mantle convection, and tectonic 'historical contingency': a resolution of the 'ophiolite conundrum'. In: Dilek Y., Moores E. M., Elthon D. \& Nicolas A. eds. Ophiolites and Oceanic Crust: New Insights from Field Studies and the Ocean Drilling Program, pp. 3-12. Geological Society of America Special Paper 349.

NAVON O. \& StolPER E. 1987. Geochemical consequences of melt percolation: the upper mantle as a chromatographic column. Journal of Geology 95, 285-307.

NIU Y. 2004. Bulk-rock major and trace element compositions of abyssal peridotites: implications for mantle melting, melt extraction and post-melting processes beneath mid-ocean ridges. Journal of Petrology 45, 2423-2458.

O’Brien G. W., Etheridge M. A., Willcox J. B., Morse M., SyMONDS P., NoRMAN C. \& NEEDHAM D. J. 1993. The structural architecture of the Timor Sea, north-western Australia: implications for basin development and hydrocarbon exploration. The APEA Journal 33, 258-278.

Olive V., Ellam R. M. \& Wilson L. 2001. A protocol for the determination of the rare earth elements at picomole level in rocks by ICP-MS: results on geological reference materials USGS PCC-1 and DTS-1. Geostandards Newsletter 25, 219-228.

Parkinson I. J. \& PEARCE J. A. 1998. Peridotites from the IzuBonin-Mariana forearc (ODP Leg 125): evidence for mantle melting and melt-mantle interaction in a supra-subduction zone setting. Journal of Petrology 39, 1577-1618.

Parkinson I. J., Pearce J. A., Thirlwall M. F., Johnson K. T. M. \& INGRAM G. 1992. Trace element geochemistry of peridotites from the Izu-Bonin-Mariana forearc, Leg 125. In: Fryer P., Pearce J. A., Stokking L. B. et al. eds. Proceedings of the Ocean Drilling Program Scientific Results, 125. pp. 487-506. Ocean Drilling Program, College Station, TX.

Pearce J. A., Alabaster T., Shelton A. W. \& Searle M. P. 1981. The Oman ophiolite as a Cretaceous arc-basin complex: evidence and implications. Philosophical Transactions of the Royal Society of London 300, 299-317.

Pearce J. A., Barker P. F., Edwards S. J., Parkinson I. J. \& LEAT P. T. 2000. Geochemistry and tectonic significance of peridotites from the South Sandwich arc-basin system, South Atlantic. Contributions to Mineralogy and Petrology 139, 36-53.

PRINZHOFER A. \& ALLĖGRE C. J. 1985. Residual peridotites and the mechanisms of partial melting. Earth and Planetary Science Letters 74, 251-265.

QI L., ZHOU M.-F., MALPAS J. \& SUN M. 2005. Determination of rare earth elements and $\mathrm{Y}$ in ultramafic rocks by ICP-MS after preconcentration using $\mathrm{Fe}(\mathrm{OH})_{3}$ and $\mathrm{Mg}(\mathrm{OH})_{2}$ coprecipitation. Geostandards and Geoanalytical Research 29, 131-141.

Quick J. E. 1981. The origin and significance of large, tabular dunite bodies in the Trinity Peridotite, northern California. Contributions to Mineralogy and Petrology 78, 413-422. 
Rampone E., Hofmann A. W., Piccardo G. B., Vannucci R., BotTAzZi P. \& OTTOLINI L. 1995. Petrology, mineral and isotope geochemistry of the external liguride peridotites (Northern Apennines, Italy). Journal of Petrology 35, 81-105.

RAMPONE E. \& PICCARDO G. B. 2000. The ophiolite-oceanic lithosphere analogue: new insights from the Northern Apennines (Italy) In: Dilek Y., Moores E. M., Elthon D. \& Nicolas A. eds. Ophiolites and Oceanic Crust: New insights from Field Studies and the Ocean Drilling Program, pp. 21-34. Geological Society of America Special Paper 349.

RoBINSON P. 2003. XRF analysis of flux-fused discs. Geoanalysis 2003, 5th International Conference on the Analysis of Geological and Environmental Materials, Abstracts, 90.

RoBinson P., TOWNSEND A. T., YU Z. \& MÜNKeR C. 1999. Determination of scandium, yttrium and rare earth elements in rocks by high resolution inductively coupled plasma-mass spectrometry. Geostandards Newsletter 23, 31-46.

RUDNICK R. L., BARTH M., HoRN I. \& MCDONOUGH W. F. 2000. Rutilebearing refractory eclogite: missing link between continents and depleted mantle. Science 287, 278-281.

SHARMA M. \& WASSERBURG G. J. 1996. The neodymium isotopic compositions and rare earth patterns in highly depleted ultramafic rocks. Geochimica et Cosmochimica Acta 60, 4537-4550.

Sopaheluwakan J., Helmers H., TJokrosapoetro S. \& Nila E. S. 1989. Medium pressure metamorphism with inverted thermal gradient associated with ophiolite nappe emplacement in Timor. Netherlands Journal of Sea Research 24, 333-343.

Stolz A. J., Jochum K. P., Spettel B. \& Hofmann A. W. 1996. Fluidand melt-related enrichment in the subarc mantle: evidence from $\mathrm{Nb} / \mathrm{Ta}$ variations in island-arc basalts. Geology 24, 587-590.

STоSCH H-G. \& SECK H. A. 1980. Geochemistry and mineralogy of two spinel peridotite suites from Dreiser Weiher, West Germany. Geochimica et Cosmochimica Acta 44, 457-470.

Sun S-S. \& MCDONOUGH W. F. 1989. Chemical and isotopic systematics of oceanic basalts: implications for mantle composition and processes. In: Saunders A. D. \& Norry M. J. eds. Magmatism in the Ocean Basins, pp. 313-345. Geological Society of London Special Publication 42.

TAKaZAwa E., Frey F. A., Shimizu N. \& Obata N. 2000. Whole rock compositional variations in an upper mantle peridotite (Horoman, Hokkaido, Japan): are they consistent with a partial melting process? Geochimica et Cosmochimica Acta 64, 695-716.
TAKAZAWA E., Frey F. A., Shimizu N., OBATA M. \& BodinieR J-L. 1992. Geochemical evidence for melt migration and reaction in the upper mantle. Nature 359, 55-58.

TAKaZaWa E., OKayasu T. \& SaToH K. 2003. Geochemistry and origin of the basal lherzolites from the northern Oman ophiolite (northern Fizh block). Geochemistry Geophysics, Geosystems 4, 8605. DOI 10.1029/2001GC000232.

Tiepolo M., Vannucci R., Oberti R., Foley S., Bottazzi P. \& ZANETTI A. 2000. $\mathrm{Nb}$ and Ta incorporation and fractionation in titanian pargasite and kaersutite: crystal chemical constraints and implications for natural systems. Earth and Planetary Science Letters 176, 185-201.

TROPPER P. \& MANNing C. E. 2005. Very low solubility of rutile in $\mathrm{H}_{2} \mathrm{O}$ at high pressure and temperature, and its implications for Ti mobility in subduction zones. American Mineralogist 90, 502 505.

VAN DER WAL D. \& BODINIER J-L. 1996. Origin of the recrystallization front in the Ronda peridotite by $\mathrm{km}$-scale pervasive porous melt flow. Contributions to Mineralogy and Petrology 122, 387 405.

Weyer S., MunkeR C. \& Mezger K. 2003. Nb/Ta, Zr/Hf and REE in the depleted mantle: implications for the differentiation history of the crust mantle system. Earth and Planetary Science Letters 205, 309-423.

Weyer S., MÜNker C., RehKaemper M. \& Mezger K. 2002. Determination of ultra-low $\mathrm{Nb}, \mathrm{Ta}, \mathrm{Zr}$ and $\mathrm{Hf}$ concentrations and the chondritic $\mathrm{Zr} / \mathrm{Hf}$ and $\mathrm{Nb} / \mathrm{Ta}$ ratios by isotope dilution analyses with multiple collector ICP-MS. Chemical Geology 187, $295-313$.

Willbold M. \& Jochum K. P. 2005. Multi-element isotope dilution sector field ICP-MS: a precise technique for the analysis of geological materials and is application to geological reference materials. Geostandards and Geoanalytical Research 29, 63-82.

Yu Z., Robinson P., TOWNSEND A. T., MÜNKER C. \& CRAWFORd A. J. 2000. Determination of HFSE, Rb, Sr, Mo, Sb, Cs, Tl and Bi at $\mathrm{ng} \mathrm{g}^{-1}$ levels in geological reference materials by magnetic sector ICP-MS after $\mathrm{HF} / \mathrm{HClO}_{4}$ high pressure digestion. Geostandards Newsletter 24, 39-50.

Received 1 July 2005; accepted 3 March 2006

\section{SUPPLEMENTARY PAPER}

Appendix 1 Comparison of literature values for international peridotite PCC-1 and values obtained in this study. 